Economics Development Analysis Journal

\title{
Dampak Revitalisasi Pasar Tradisional Terhadap Pendapatan Pedagang di Pasar Bulu Semarang
}

\section{Rizka Aprilia ${ }^{1 凶}$}

PT Indokores Sahabat, Purbalingga, Jawa Tengah

\begin{tabular}{l} 
Info Artikel \\
\hline Sejarah Artikel: \\
Diterima Januari 2017 \\
Disetujui Maret 2017 \\
Dipublikasikan Mei 2017
\end{tabular}

Keywords:

Traders Income,

Revitalization

\begin{abstract}
Abstrak
Latar belakang penelitian ini bertujuan untuk melihat dampak revitalisasi pasar tradisional terhadap pendapatan pedagang di Pasar Bulu Semarang. Jenis penelitian ini adalah kualitatif dan kuantitatif. Data dikumpulkan melalui observasi, wawancara, dan dokumentasi. Teknik analisis data menggunakan model interaktif dan uji t sampel berpasangan. Hasil menunjukan bahwa mayoritas pedagang di Pasar Bulu merupakan penduduk asli Kota Semarang. Revitalisasi tidak mengubah hubungan sosial antar pedagang, maupun pedagang dengan aparat yang selama ini terjalin dengan baik. Setelah revitalisasi kondisi bangunan Pasar Bulu menjadi lebih bersih dan rapi. Revitalisasi berdampak pada penurunan pendapatan pedagang, dibuktikan dengan hasil uji $t$ sampel berpasangan diperoleh hasil t_hitung $=10,116>\mathrm{t} \_$tabel $=2,064$ dengan probabilitas $0,000<0,05$. Rata-rata pendapatan pedagang sebelum revitalisasi sebesar Rp 5.280.000, sedangkan sesudah revitalisasi sebesar Rp 3.366.000. Kesimpulan dalam penelitian ini adalah revitalisasi berdampak pada penurunan pendapatan pedagang di Pasar Bulu Semarang.
\end{abstract}

\begin{abstract}
The basic problem of this study is to show the impact of the traditional market revitalization towards the traders income in Bulu Market Semarang. The type of this study are qualitative and quantitative. The data collected by observation, interview, and documentation. The analysis of data using interactive models and paired samples $t$ test. The result showed that the majority of traders in Bulu Market are the natives of Semarang City. The revitalization did not change the social relations between the traders, and traders with the officers who had been well maintained. After the revitalization, the Bulu Market Building condition become more clean and neart. The revitalization gives an impact towards the decreasing of the traders income, proved by the paired samples $t$ test result which showing t_hitung $=10,116>t_{-}$tabel $=2,064$ with probability 0,000 $<0,05$. The average of the traders income before revitalization $R p 5.280 .000$, meanwhile after the revitalization $R p$ 3.366.000. the conclusion in this study is the revitalization gives an impact towards the decreasing of the traders income in Bulu Market Semarang
\end{abstract}

\begin{tabular}{ll}
\hline Alamat korespondensi: & ISSN 2252-6765 \\
Jalan Ahmad Yani, No.2 & \\
Kota Purbalingga & \\
E-mail: rizkaaprilia191@gmail.com &
\end{tabular}




\section{PENDAHULUAN}

Pasar tradisional merupakan tempat bertemunya penjual dan pembeli yang ditandai dengan adanya transaksi penjualan dan pembelian secara langsung. Namun, seiring berkembangnya waktu eksistensi pasar tradisional mulai tergeserkan oleh keberadaan pasar modern. Hasil survey lembaga riset AC Nielsen menyatakan bahwa jumlah pasar tradisional di Indonesia mengalami penurunan setiap tahunnya. Pada tahun 2007 sekitar 13.550 unit, tahun 2009 sebesar 13.450 unit, dan pada tahun 2011 sebesar 9.950 unit. Sementara itu pertumbuhan pasar tradisional menurun sebesar 8,1 persen, sedangkan pertumbuhan pasar modern mencapai 31,4 persen. Pasar tradisional dan pasar modern rata-rata mempunyai spesifikasi barang dagangan yang hampir sama sehingga berpeluang mengakibatkan terjadi persaingan diantara dua pasar tersebut. Jika dibiarkan persaingan bebas antara kedua pasar tersebut dapat menggeser keberadaan pasar tradisional (Ratnasari, 2015).

Kota Semarang sebagai ibukota Provinsi Jawa Tengah merupakan salah satu kota terbesar dan memiliki potensi yang tinggi dalam hal perdagangan. Pada Kota Semarang pertumbuhan pasar modern lebih cepat jika dibandingkan dengan pertumbuhan pasar tradisional yang dapat dilihat dari tabel di bawah ini:

Tabel 1. Banyaknya Pasar dan Jenis Pasar di Kota Semarang Tahun 2010-2014

\begin{tabular}{|c|c|c|}
\hline Tahun & $\begin{array}{c}\text { Pasar } \\
\text { Tradisional }\end{array}$ & $\begin{array}{c}\text { Pasar } \\
\text { Modern }\end{array}$ \\
\hline 2010 & 55 & 64 \\
\hline 2011 & 55 & 64 \\
\hline 2012 & 55 & 65 \\
\hline 2013 & 55 & 65 \\
\hline 2014 & 55 & 65 \\
\hline
\end{tabular}

Sumber: BPS Kota Semarang 2015

Berdasarkan tabel diatas dapat dilihat bahwa jumlah pasar modern lebih tinggi jika dibandingkan dengan jumlah pasar tradisional, yaitu terdapat 65 pasar modern dan 55 pasar tradisional. Pemerintah Kota Semarang telah mencanangkan kebijakan program revitalisasi pasar tradisional untuk mengatasi lambatnya pertumbuhan pasar tradisional. Kebijakan revitalisasi pasar tradisional tercantum dalam Rencana Pembangunan Jangka Menengah Daerah (RPJMD) tahun 2011-2015.

Pasar Bulu Kota Semarang merupakan salah satu pasar tradisional yang menjadi target revitalisasi. Program revitalisasi terhadap Pasar Bulu diagendakan pada Rencana Pembangunan Jangka Panjang Daerah (RPJP) tahun 2005-2025 dengan visi "Terwujudnya Semarang Kota Perdagangan dan Jasa, yang Berbudaya Menuju Masyarakat Sejahtera". Ada beberapa alasan mengapa perlu diadakannya revitalisasi pada Pasar Bulu yaitu terkait kondisi Pasar Bulu yang tidak bisa berkembang dengan baik. Kondisi Pasar Bulu terkesan kumuh, kotor, pengap, dan daya tampung pasar untuk pedagang tidak memadai. Selain adanya faktor tersebut, Pemerintah merevitalisasi Pasar Bulu dengan tujuan untuk melakukan penataan pedagang dan pengembangan pasar tradisional dengan konsep semi modern. Dalam proses revitalisasi diperlukan adanya inovasi pasar dengan mengubah cara bisnis yang dilakukan (Kjellberg, et al, 2015).

Kebijakan revitalisasi mencakup tiga aspek yang diantaranya aspek sosial budaya, aspek ekonomi, dan aspek fisik. Dalam proses inovasi pasar diperlukan perluasan unit pasar, pengembangan ruang lingkup pasar dan perbaikan struktur kerja pasar (Storbacka dan Suvi, 2015). Pada aspek sosial budaya, peraturan zonasi yang mengelompokan pedagang menurut jenis dagangan menyebabkan persaingan diantara pedagang. Selain itu adanya pelanggaran aturan zonasi dapat memicu konflik diantara pedagang karena dianggap merugikan bagi pedagang lain yang sejenis. Pelaksanaan kebijakan revitalisasi juga dapat menyebabkan kesalahpahaman diantara pedagang dan aparat yang dapat merubah hubungan sosial yang selama ini telah terjalin dengan baik. Selain berdampak pada aspek sosial budaya, revitalisasi juga berdampak pada aspek ekonomi. Revitalisasi menyebabkan perubahan pendapatan bagi pedagang. Rata-rata pendapatan pedagang sebelum revitalisasi sebesar Rp. 4.650.000, sedangkan setelah revitalisasi sebesar Rp. 2.895.000. Revitalisasi tidak hanya 
berpengaruh terhadap aspek sosial budaya, dan ekonomi tetapi juga pada aspek fisik. Setelah direvitalisasi kondisi bangunan Pasar Bulu banyak mengalami perubahan yang dapat berpengaruh pada kenyamanan pedagang dan pembeli.

Penelitian ini bertujuan untuk mendeskripsikan karakteristik pedagang pasar, mendeskripsikan dampak revitalisasi pasar dari aspek sosial budaya, ekonomi, dan fisik, serta menganalisis dan menghitung dampak revitalisasi terhadap pendapatan pedagang di Pasar Bulu Semarang.

\section{METODE PENELITIAN}

\section{Jenis Penelitiaan}

Penelitian ini menggunakan metode kualitatif dan kuantitatif. Metode kualitatif digunakan untuk mendeskripsikan karakteristik pedagang di Pasar Bulu Semarang, aspek sosial budaya, ekonomi, dan fisik dari adanya revitalisasi di Pasar Bulu Semarang. Metode kuantitatif digunakan untuk menganalisis dampak revitalisasi terhadap pendapatan pedagang di Pasar Bulu Semarang.

\section{Sumber Data}

Data yang digunakan dalam penelitian ini adalah data primer dan data sekuder. Data primer dalam penelitian ini diperoleh dari observasi ataupun wawancara langsung dengan Dinas Pasar Kota Semarang, Kepala UPTD Pasar Bulu, dan pedagang di Pasar Bulu. Sedangkan data sekunder adalah data yang diperoleh dari instansi terkait yaitu Dinas Pasar Kota Semarang seperti, data jumlah pedagang di Pasar Bulu, dan jumlah pasar di Kota Semarang.

\section{Teknik Pengumpulan Data}

\section{a. Wawancara}

Penelitian ini dilakukan wawancara kepada Dinas Pasar Kota Semarang, Kepala UPTD Pasar Bulu, dan Pedagang di Pasar Bulu. Wawancara yang dilakukan kepada pedagang menggunakan purposive sampling dan snowbaal sampling.

b. Dokumentasi

Peneliti menggunakan dokumentasi sebagai sarana untuk mendapatkan data tentang identitas Pasar Bulu, lahan dan bangunan pasar, jumlah pedagang, sarana dan prasarana pasar, operasional dan pengelola pasar, serta jumlah petak pedagang.

c. Observasi

Observasi ini bertujuan untuk memperoleh data tentang keadaan di Pasar Bulu, khususnya pedagang yang ada dan aktivitas yang dilakukan pedagang di Pasar Bulu dari proses berdagang di pasar tersebut.

\section{Model Analisis Data}

Penelitian ini menggunakan analisis data model interaktif dan Uji t Sampel berpasangan. Analisis model interaktif digunakan untuk menjawab fokus penelitian yaitu karakteristik pedagang di Pasar Bulu Semarang, dan dampak revitalisasi pasar dari aspek sosial budaya, ekonomi, dan fisik di Pasar Bulu Semarang. Tahapan analisisnya yaitu pengumpulan data, reduksi data, penyajian data, serta pengambilan keputusan atau verifikasi.

Langkah-langkah analisis data ditunjukan pada gambar dibawah ini :

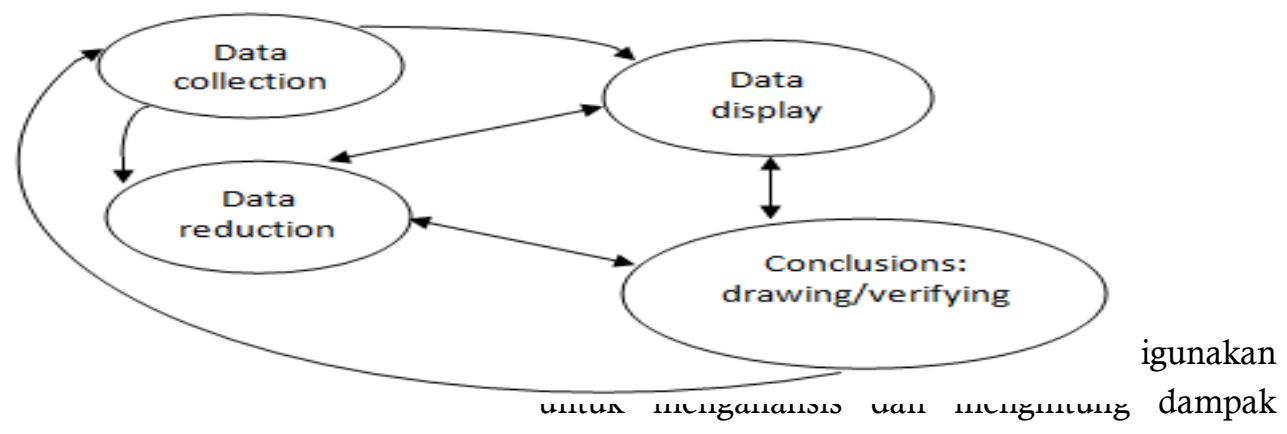

Komponen dalam analisis data (interactive model), revitalisasi terhadap pendapatan pedagang di model Miles dan Huberman (1984) 


$$
t=\frac{\overline{X_{1}}-\overline{X_{2}}}{\sqrt{\frac{s_{1}^{2}}{n_{1}}+\frac{s_{2}{ }^{2}}{n_{2}}-2 r\left(\frac{s_{1}}{\sqrt{n_{1}}}\right)\left(\frac{s_{2}}{\sqrt{n_{2}}}\right)}}
$$

Pasar Bulu Semarang, dengan formulasi

sebagai berikut:

Keterangan:

$\overline{x_{1}}=$ Rata-rata pendapatan pedagang sebelum revitalisasi pasar

$\overline{x_{2}}=$ Rata-rata pendapatan pedagang sesudah revitalisasi pasar

$s_{1}=$ Simpangan baku pendapatan pedagang sebelum revitalisasi pasar

$s_{2}=$ Simpangan baku pendapatan pedagang sesudah revitalisasi pasar

$n_{1}=$ Jumlah pendapatan pedagang sebelum revitalisasi pasar

$n_{2}=\mathrm{J}$ umlah pendapatan pedagang sesudah revitalisasi pasar3

Perhitungan uji $t$ sampel berpasangan menggunakan software SPSS versi 16,0, dengan pengambilan keputusan sebagai berikut:

a. Jika probabilitas $>0,05$, maka $\mathrm{H}_{0}$ diterima dan $\mathrm{H}_{\mathrm{a}}$ ditolak, sehingga tidak terdapat perbedaan pendapatan pedagang sebelum dan sesudah revitalisasi

b. Jika probabilitas $<0,05$, maka $\mathrm{H}_{0}$ ditolak dan $\mathrm{H}_{\mathrm{a}}$ diterima, sehingga terdapat perbedaan pendapatan pedagang sebelum dan sesudah revitalisasi

\section{HASIL DAN PEMBAHASAN}

\section{Karakteristik Pedagang di Pasar Bulu Kota Semarang}

Pedagang pasar merupakan seseorang yang mempunyai usaha dan tempat permanen, dimana terjadi apabila ada komunikasi antara penjual dan pembeli yang kemudian diakhiri dengan keputusan untuk membeli suatu barang. Pedagang yang akan dibahas dalam penelitian ini adalah pedagang yang berjualan di Pasar Bulu Kota Semarang. Penelitian ini akan mendeskripsikan karakteristik pedagang di Pasar Bulu Kota Semarang yang diantaranya bersisi tentang jenis dagangan yang dijual oleh pedagang, lama berjualan, usia, jenis kelamin, tingkat pendidikan, serta alamat atau tempat tinggal pedagang.

Dari hasil penelitian menunjukan bahwa mayoritas pedagang di Pasar Bulu merupakan penduduk asli Kota Semarang. Pedagang pendatang dari luar Kota Semarang hanya sedikit jumlahnya. Pedagang di dominasi oleh kalangan wanita yang berusia 26 sampai 70 tahun. Lama berjualan pedagang berkisar antara lima hingga 50 tahun. Tingkat pendidikan pedagang sebagian besar adalah lulusan dari sekolah menengah atas atau sekolah menengah kejuruan (SMA/SMK). Tingkat pendidikan tertinggi pedagang yaitu hingga jenjang diploma, sedangkan yang terendah yaitu tidak bersekolah.

Aspek Sosial Budaya, Ekonomi, dan Fisik dari Revitalisasi di Pasar Bulu Semarang Aspek Sosial Budaya

Aspek sosial budaya dalam revitalisasi Pasar Bulu Kota Semarang meliputi hubungan sosial antar pedagang, dan hubungan sosial pedagang dengan aparat setelah adanya revitalisasi. Setelah adanya revitalisasi pasar, diberlakukan peraturan zonasi yang mengubah letak berdagang para pedagang menjadi berdekatan, dan mengelompok sesuai dengan jenis dagangannya. Efisiensi pasar bervariasi sesuai dengan konsumen dan produknya (Jiang dan Siva, 2014). Peraturan zonasi ini justru dilanggar oleh beberapa pedagang yang dengan sengaja berjualan tidak sesuai dengan lokasi yang telah ditentukan. Hal ini dapat merubah hubungan sosial antar pedagang yang selama ini terjalin dengan baik. Selain berdampak terhadap hubungan sosial antar pedagang, revitalisasi juga berdampak pada hubungan sosial pedagang dengan aparat. Aparat yang dimaksud adalah pengelola Pasar Bulu Kota Semarang, dan Dinas Pasar Kota Semarang. Adanya revitalisasi di Pasar Bulu Kota Semarang dapat mempengaruhi hubungan sosial antara pedagang dan aparat yang selama ini sudah terjalin dengan baik. Dalam pelaksanaan revitalisasi tidak menutup kemungkinan terjadinya konflik kepentingan antara pedagang dengan aparat.

Hasil penelitian menunjukan bahwa revitalisasi tidak merubah hubungan sosial antar pedagang yang selama ini telah terjalin dengan 
baik. Peraturan mengenai pengelompokan pedagang sejenis tidak menyebabkan persaingan yang tidak sehat diantara mereka. Begitu pula hubungan sosial pedagang dengan pihak aparat tidak menunjukan adanya perubahan. Hubungan pedagang dengan aparat tetap terjalin dengan baik. pedagang dan aparat pasar justru saling membantu untuk membuat pasar menjadi lebih baik.

\section{Aspek Ekonomi}

Mayoritas pedagang di Pasar Bulu mengalami perubahan pendapatan. Perubahan pendapatan pedagang di sebabkan oleh berkurangnya minat pengunjung untuk masuk ke dalam pasar. Berkurangnya pengunjung disebabkan oleh beberapa faktor yang diantaranya yaitu tarif parkir kendaraan yang terlalu mahal, pembeli kesulitan menjangkau lantai dua dan tiga pasar saat eskalator dimatikan, akses keluar masuk pasar yang membingungkan, serta kesulitan pembeli mencari penjual yang diinginkan. Perubahan pendapatan tidak hanya dirasakan oleh pedagang di lantai tiga saja, namun juga pedagang di lantai satu dan lantai dua pasar. Pedagang yang mengalami perubahan pendapatan, melakukan usaha lain untuk meningkatkan pendapatannya. Usaha lain yang di lakukan pedagang yaitu dengan cara berjualan keliling atau membuka bazar di tempat lain setelah atau pada saat tidak berjualan di Pasar Bulu. Dengan usaha seperti ini di harapkan mampu meningkatkan pendapatan pedagang.

\section{Aspek Fisik}

Revitalisasi Pasar Bulu Kota Semarang dilakukan untuk mengubah citra pasar yang terkesan kotor, kumuh, dan tidak berkembang dengan baik, menjadi pasar kota yang sehat. Setelah di revitalisasi dalam kurun waktu tiga tahun, Pasar Bulu kembali di fungsikan pada tahun 2014. Pasar Bulu yang di desain dengan konsep semi modern ini memiliki struktur bangunan tiga lantai dengan fasilitas yang meliputi eskalator, lift barang, kios, los, dasaran terbuka (pancaan), pos keamanan, kantor pasar, gudang, sarana parkir yang memadai untuk 150 mobil dan 300 sepeda motor, mushola, kamar mandi (WC), sarana loading barang, pompa drainage, CCTV, dan sebagainya.

Bangunan Pasar Bulu terlihat lebih megah setelah di revitalisasi. Bangunan fisik pasar menjadi lebih bagus dan bersih, tempat berjualan juga lebih tertata dengan baik. Namun, tidak semua orang beranggapan bahwa bangunan pasar yang sekarang lebih baik ini nyaman untuk digunakan. Mereka memiliki keluhan tersendiri mengenai bangunan fisik pasar, terutama bagi mereka para pedagang yang menempati bangunan tersebut. Bagi pedagang yang merasa nyaman mereka mengungkapkan bahwa bangunan Pasar Bulu menjadi lebih bersih, bagus, dan tempat berjualan terlihat lebih rapi. Namun bagi pedagang yang merasa tidak nyaman dengan kondisi pasar setelah revitalisasi, mereka mengeluhkan kondisi lantai dua pasar tidak memiliki sirkulasi udara yang baik karena kurangnya ventilasi. Fasilitas di pasar tidak berfungsi dengan baik (saluran air bersih tidak berfungsi,dan belum ada pembuangan untuk limbah cair), serta banjirnya lantai tiga saat terjadi hujan, karena belum adanya kanopi.

Hasil penelitian menunjukan bahwa pasca revitalisasi kondisi bangunan pasar bulu menjadi lebih bagus, bersih, dan rapi. Citra pasar yang terkesan kotor, kumuh, dan tidak tertata dengan baik, berubah menjadi bersih, rapi, dan sehat. Pedagang juga merasa nyaman menempati pasar saat ini, hal ini karena tempat berjualan untuk pedagang jauh lebih nyaman. Namun, perlu pembenahan fasilitas pasar terutama di lantai dua dan lantai tiga pasar, serta perlu pembenahan pada fasilitas parkir kendaraan.

\section{Dampak Revitalisasi Terhadap Pendapatan Pedagang Sebelum dan Sesudah Revitalisasi di Pasar Bulu Semarang}

Adanya revitalisasi Pasar Bulu tidak hanya berdampak pada aspek sosial, dan fisik saja, akan tetapi berdampak pada perekonomian pedagang. Variabel ekonomi yang dimaksud dalam penelitian ini adalah pendapatan pedagang. Pendapatan pedagang merupakan hasil berupa uang yang di dapatkan pedagang dari hasil berdagang di Pasar Bulu. Pendapatan pedagang dalam penelitian ini adalah pendapatan bersih rata-rata setiap bulan yang di peroleh pedagang 
pada saat berjualan di Pasar Bulu sebelum dan sesudah adanya revitalisasi pasar.

Hasil penelitian menunjukan bahwa revitalisasi berdampak pada penurunan pendapatan pedagang di Pasar Bulu Kota Semarang. Hal ini dibuktikan dengan hasil uji t sampel berpasangan (Paired-Samples T Test) yang menunjukan hasil bahwa terdapat perbedaan yang signifikan antara pendapatan pedagang sebelum dan sesudah revitalisasi pasar. Dari hasil perhitungan menggunakan program SPSS versi 16.0 diperoleh hasil $t_{\text {hitung }}=10,116$ lebih besar dari $t_{\text {tabel }}=2,064$ dengan probabilitas 0,000 lebih kecil dari 0,05 . Jadi dapat dikatakan bahwa terdapat perbedaan pada pendapatan pedagang antara sebelum dan sesudah adanya revitalisasi pasar.

\section{SIMPULAN}

Berdasarkan hasil penelitian dan hasil pembahasan dapat disimpulkan bahwa Mayoritas pedagang yang berjualan di Pasar Bulu adalah penduduk asli kota Semarang. Revitalisasi Pasar Bulu mempengaruhi aspek sosial budaya, ekonomi, dan fisik di Pasar Bulu Semarang. Revitalisasi Pasar Bulu berdampak pada penurunan pendapatan bagi para pedagang di Pasar Bulu Semarang.

Saran dalam penelitian ini bagi Pemerintah sebaiknya meninjau ulang kondisi fisik pada lantai dua dan lantai tiga pasar sesuai dengan keluhan pedagang. Pedagang di Pasar Bulu seharusnya menaati peraturan yang telah disepakati dengan Dinas Pasar Kota Semarang. Guna meningkatkan pendapatan pedagang perlu adanya kerjasama antara Dinas Pasar Kota Semarang dengan pedagang di Pasar Bulu Semarang.

\section{DAFTAR PUSTAKA}

Arikunto, Suharsimi. 2006. Prosedur Penelitian Suatu Pendekatan Praktik. Jakarta: PT. Rineka Cipta.

Ayuningsasi, Anak Agung Ketut. 2010. Analisis Pendapatan Pedagang Sebelum dan Sesudah Program Revitalisasi Pasar Tradisional di Kota Denpasar (Studi
Kasus Pasar Sudha Merta Desa Sidakarya. Jurnal Piramida. 7(1): 1-11

BPS Kota Semarang. 2015. Kota Semarang Dalam Angka.

Damsar, dan Indrayani. 2013. Sosiologi Ekonomi. Jakarta:Kencana Prenadamedia Group.

Endarwati, Susilo dan Wahyuningsih, Christine. 2012. Dampak Relokasi Pasar Studi Kasus Di Pasar Sampangan Kota Semarang. Jurnal Ilmiah. UNTAG Semarang.

Jaya, Rian, Nuridja, Made, dan Suwena2, Kadek. 2014. Analisis Pendapatan Pedagang (Studi Pada Pasar Anyar Di Kelurahan Banjar Tengah). Jurnal Ekonomi dan Bisnis. 4(1): 1-10

Jiang, Pingjun dan Siva K. Balasubramaniah. 2014. An Empirical Comparison of Market Efficiency: Electronic Marketplaces vs Traditional Retail Formats. Electronic Commerce Research and Applications, Volume 13, Pages 98-109.

Kjellberg, Hans, et al. 2015. Market Innovation Processes: Balancing Stability and Change. Industrial Marketing Management, Volume 44, Pages 4-12.

Malano, Herman. 2011. Selamatkan Pasar Tradisional. Jakarta: Gramedia Pustaka Utama.

Martokusumo, Widjaja. 2006. Revitalisasi dan Rancang Kota. Jurnal Perencanaan Wilayah dan Kota. 17(3): 31-46

Pemerintah Kota Semarang. Strategi dan Kebijakan Rencana Pembangunan Jangka Menengah Daerah (RPJMD) Kota Semarang Tahun 2010-2015.

Peraturan Menteri Perdagangan No.3/MDAG/PER/1/2010 tentang Rencana Strategis Kementrian Perdagangan Tahun 2010-2014.

RATNASARI, Mentari Indah. DAMPAK SOSIAL EKONOMI REVITALISASI PASAR SAMPANGAN BAGI PEDAGANG DI KOTA SEMARANG. Economics Development Analysis Journal, [S.1.], v. 4, n. 2, june 2015. ISSN 2252-6560.

Storbacka, Kaj dan Suvi Nenonen. 2015. Learning with the Market : Facilitating Market Innovation. Industrial Marketing Management, Volume 44, Pages 73-82.

Sugiyono. 2010. Metode Penelitian Pendidikan. Bandung: Alfabeta.

Sugiyono. 2013. Metode Penelitian Kuantitatif Kualitatif dan $R \& D$. Bandung:Alfabeta. 
Rizka Aprilia / Economics Development Analysis Journal 6 (2) (2017)

Wahana Komputer. 2009. Pengolahan Data Statistik dengan SPSS 16.0. Jakarta: Salemba Infotek 